\title{
INTRODUCTION: WRITING JEWS AND JEWISHNESS IN CONTEMPORARY BRITAIN
}

\author{
Axel Stähler* and Sue Vice**
}

Several of the articles gathered in this special issue are based on papers presented at the symposium on 'Writing Jews in Contemporary Britain' held at and generously funded by the Pears Institute for the Study of Antisemitism on 11 September 2013, and co-convened by the editors together with the Institute's director, David Feldman. Others have been especially commissioned for the issue. Thanks are also due to Jan Davison, Jonathan Magonet and Jenny Pizer.

The beginning of the twenty-first century has seen what has been described as a dazzling burst in the productivity of British Jewish literature. This writing is characterized by a new confidence that, in terms of postcolonial theory, has been called a form of writing back. Contemporary British Jewish writers are being credited with an 'attitude" and their fiction is perceived to celebrate 'the anarchic potential of the Jewish voice'. ${ }^{2}$ The recent award of the Man Booker Prize to Howard Jacobson (2010) has continued the series of prestigious literary prizes won by British Jewish writers - for instance, Harold Pinter (Nobel Prize for Literature, 2006), Naomi Alderman and Linda Grant (Orange Prize, 2006 and 2000, respectively), James Lasdun (New York Times Notable Book of the Year Award, 2002), Trezza Azzopardi (Geoffrey Faber Memorial Prize, 2001) and Esther Morgan (Jerwood Aldeburgh First Collection Prize, 2001).

Yet despite this sense of cultural richness doubts linger as to the reach and the resilience of this newfound expressiveness, and a sense remains of exclusion from the mainstream of British cultural life. The very names of the prize-winning writers mentioned above invite challenging questions as to their 'Jewishness' and 'Britishness', and the issue of identity still seems to be crucial not only to British Jewish writing but also to its critical appreciation. Without claiming to know all the answers - yes, plural - this special issue of European Judaism therefore poses the question: 'What is British Jewish writing?' All the contributions to the present special issue respond to this question by considering the nature of such a hyphenated identity and the writing practice which represents it, in relation to a range of fictional, poetic,

* Dr Axel Stähler is Reader in Comparative Literature in the School of European Culture and Languages at the University of Kent, and has published widely on modern Jewish literature and on Holocaust writing.

** Sue Vice is Professor of English Literature at the University of Sheffield. Her latest book is Textual Deceptions, a study of literary hoaxes and false memoirs. 
dramatic, televisual and filmic examples, culminating in an interview with a creator of such a writing practice. ${ }^{3}$ In the opening essay, Ruth Gilbert examines recent examples of fiction and memoir which reveal a shift among British Jewish writers from an anxiety about not being wholly British, to one about concern with being insufficiently or only partially Jewish. Gilbert concludes that this contemporary version of identity anxiety can devolve more positively into an expression of fluidity rather than fragmentariness. David Brauner continues such speculation in his analysis of Howard Jacobson's fiction, in particular his novel Kalooki Nights (2006), which raises in blackly comic form questions about the relation of British Jewish writing to its American counterpart, particularly that of Philip Roth, and to the European tragedy of the Holocaust. Peter Lawson, in his article on poetry, argues for a specifically British Jewish 'diasporic poetics', evident in the themes and the imagery of work by three generations of poets: Isaac Rosenberg, Jon Silkin and, most recently, Lawson himself. The tropes of such a diasporic identity are explored in Tony Hammond's reconsideration of the troubling figure of Goldberg in Harold Pinter's play The Birthday Party (1958), of whom Hammond argues that the character's recognizability as a Jewish construct should invite spectators to question the very notion of construction of this kind. James Jordan continues the examination of audience responses to Jewish-related figures in examples from such television classics as the talk show Face to Face (1959-1962) and sitcom Please Sir! (1968-1972) as well as Simon Schama's recent series The Story of the Jews (2013), concluding with the suggestion that even the paradigmatically British Doctor Who might be identified as Jewish. Rachel Garfield too argues that elements of Jewishness are necessary to British film in her analysis of Guy Ritchie's Snatch (2000), in which gentile gangsters enact the roles of Hasidic diamond-merchants, in a way that appears to endorse a multicultural Britishness while in fact undercutting it. In an opposite formation, Nathan Abrams presents evidence not only for the profoundly Jewish concerns of the filmmaker Stanley Kubrick's works, but also for the significance of Kubrick's view of Britain as his adopted home for over three decades. The special issue concludes fittingly with Axel Stähler's interview with the British Jewish novelist and short-storywriter Clive Sinclair, who names his tellingly varied influences as Kafka, Roth and Shakespeare, and describes his own affiliation as 'existentially Jewish'.

In order to contextualize the eight essays which make up the bulk of this special issue, to explore the legitimacy and meaning of the literary category of British Jewish writing and to examine it in terms of its history and current manifestations, in its relation to changing sociocultural contexts, its dialogue with various literary traditions and its negotiation of questions of identity, the remainder of this introduction attempts to give a necessarily much 
abbreviated historical overview of Jewish writing and some of its distinctive developments in postwar Britain.

Just days after the decisive Six-Day War of 1967, when the pro-Israeli euphoria of many Jews in the diaspora was at its height, and shortly after a group of more than thirty London-based Jewish authors had signed an open letter to The Sunday Times (4 June 1967) to voice their anxiety about Israel's precarious position, ${ }^{4}$ the British writer Philip Toynbee observed in a review of two Jewish American novels that there was 'something very like a recognizable school of American-Jewish fiction' or - phrased more carefully, because he also perceived that there were 'some writers who are both Jewish and American [who] do not belong to it' - that there were at least many Jewish writers in America 'whose principal purpose and function is the exploration of a specifically Jewish experience; the attempt to define various forms of Jewish identity'. ${ }^{5}$ Toynbee concluded quite categorically that no such phenomenon was to be found in Britain.

The two novels reviewed by the British writer for the American magazine The New Republic were Chaim Potok's The Chosen (1967) and Herbert Gold's Fathers (1967). In his discussion, Toynbee acknowledged as distinctively Jewish American in these texts the literary engagement with the immigrant experience and the conflict of generations, of 'fathers who have never been able to turn themselves into Americans' with 'sons who are American by both birth and inclination'. ${ }^{6}$ As another attribute, he identified 'the old EuropeAmerica dichotomy', because, as the reviewer suggests, 'a major American preoccupation has always been the conflict, in the American mind and soul, between a Europe which has never been quite rejected and a native American mind which has never stood quite on its own without being very conscious of its novel and exhilarating stance'. ${ }^{7}$ Both characteristics may arguably also be considered typical of other immigrant literatures, even though the particulars of the cultural baggage from the old world which informs any attempt at defining various Jewish identities in the USA and the engagement with the 'Europe-America dichotomy' may be specific.

Yet Toynbee's claim that no similarly coherent phenomenon was to be observed in Britain chimes with Brian Glanville's earlier assertion, in 1960, that there were Anglo-Jewish writers but 'no such thing as Anglo-Jewish writing'. ${ }^{8}$ Glanville's doubts about the existence of an Anglo-Jewish literary tradition may have been fuelled by the controversy elicited by his novel The Bankrupts (1958) among the Anglo-Jewish establishment. The British Jewish writer had been sharply criticised for his description of the Jewish community in northwest London as materialist and devoid of inner values 
and after his second 'Jewish' novel, Diamond (1962), completely abandoned Jewish subjects. ${ }^{9}$ However, Glanville's scepticism was shared by other AngloJewish writers. In a series of interviews conducted by the controversial author between 1958 and 1959 for the London Jewish Chronicle it emerged that all of those questioned were either indifferent to, or dismissive of, the AngloJewish community and did not see themselves in a continuous Anglo-Jewish literary tradition..$^{10}$ The dramatist Peter Shaffer went so far as to suspect the very question to reveal a neurotic disorder and to be indicative of AngloJewry's endemic crisis of identity:

Don't you think that a group which has its reason for existing as a separate national group taken away, and which is increasingly losing its religious insights, will get increasingly neurotic and insistent on tradition? I think the last despairing call of a culture is to its past. ${ }^{11}$

Of the six writers interviewed by Glanville, only four signed the open letter to The Sunday Times which asserted Israel's 'right to live', nor was Brian Glanville himself among the signatories. ${ }^{12}$ This, in itself, may suggest a certain lack of coherence, if only in relation to the highly sensitive and potentially divisive political issue of Israel on the very eve of the Six-Day War. ${ }^{13}$ What the list of the undersigned also reveals, however, is the surprising diversity of Jewish authors based in Britain and writing in English at the time and, after all, a feeling - if perhaps rather vague - of solidarity. ${ }^{14}$

In fact, the names of British-born Jewish authors who signed the letter, though by no means exhaustive, are indicative of centres of Jewish life in Britain - Wales, Liverpool and Manchester, as well as, of course, London's East End. The list of signatories as a whole is, moreover, illustrative of the far-flung reaches of the Anglophone Jewish diaspora in which many of these writers either had their cultural roots or to which they were attracted after the cataclysm of the Holocaust. Indeed, with the conspicuous exception of the antipodean, most of the undersigned authors hail from Britain and its former colonies or dominions and from America - among them Mordecai Richler, Frederic Raphael, Ronald Harwood and Dan Jacobson. Most of them have, beyond this, diverse other linguistic and cultural affiliations in their personal memories or in the heritage of their families, the very immigrant experience referred to by Toynbee, the condition 'diasporic'. In a manner of speaking, they epitomize the Anglophone Jewish diaspora in all its cosmopolitan diversity, but also in its cohesive affinities and its literary creativity and productivity.

After the disruptive events of the Second World War and the Holocaust and, finally, the incisive foundation of the state of Israel, the productivity of British Jewish writers burgeoned. Indeed, the 1950s, when writers like Harwood, Jacobson and Richler gravitated towards London, have been credited with 
bringing forth a 'new wave' of Jewish writing in Britain. Crucially, this was a time of rapid and sweeping cultural change which affected all of Britain and which saw the emergence and gradual ascendance of a plurality of ethnic voices, most conspicuously of those conveniently but controversially gathered under the label of black British literature and comprising 'politically coloured' writers from across the disintegrating British Empire, especially the Caribbean, South Asia and Africa. ${ }^{15}$

Perhaps symptomatically, a serious literary engagement with the Holocaust and Israel emerged rather late in British Jewish writing. Particular to the success of British Jewish writers in that period, such as Arnold Wesker, Harold Pinter and Alexander Baron, was rather that the context of their literary production was determined by a new awareness of their ethnicity and their working-class roots but also by their social commitment. These authors did not, however, as observed by Toynbee, develop distinctive group characteristics and, as a rule, had to rely very much on recognition beyond the relatively small British Jewish community towards which they were highly ambivalent and whose perceived complacency and hypocrisy they frequently challenged - as Brian Glanville had done, but as writers like Frederic Raphael or Bernard Kops also did. Nevertheless, many British Jewish authors also engaged with Jewish concerns in a less controversial and more committed way. Among them, Chaim Bermant, Gerda Charles, William Goldman and Chaim Raphael are perhaps the most notable.

While remaining linguistically committed to England, for many British Jewish writers, turning to non-English territories in their fiction, especially to the diaspora and, less frequently, to Israel, became a way of sidestepping the hegemony of English, or even British, constructions of the past which excluded Jewishness. This phenomenon, designated by Bryan Cheyette as 'extraterritoriality', ${ }^{16}$ has been described as the defining characteristic of much of British Jewish writing in the latter half of the twentieth century, investing it with a critical potential which challenges rigid conceptions of history and established constructions of the past as well as essentialist conceptions of identity, of which the work of Ruth Fainlight and Elaine Feinstein or Clive Sinclair and Simon Louvish provides examples - an illustrative sample of the latter's extraterritorial focus, for instance, is included in the general section of this issue of European Judaism.

The oppressiveness of a fixed Englishness which, in contrast to America, for a very long time neither permitted nor admitted the shaping influence of ethnic minorities in Britain, has also been used to explain the success of Jewish émigré writers, like Eva Figes, Gabriel Josipovici and George Steiner or Arthur Koestler, Ruth Prawer Jhabvala and Dan Jacobson; precisely because they were not bound and bounded by the historical fixity of the dominant 
culture and its unremitting pressure of assimilation. But in contemporary British Jewish writing, the 'extraterritoriality' which still informs some of the more recent voices, for instance those of Elena Lappin, Jonathan Treitel and Jonathan Wilson, has been superseded by a succinct feeling of place connected to specific locations in Britain whose particularities are confidently explored in correlation with questions of belonging and alienation. Contemporary British Jewish writers, such as Naomi Alderman, David Baddiel, Lana Citron, Jeremy Gavron, Zoe Heller, Anna Maxted, Charlotte Mendelson, William Sutcliffe and Adam Thirlwell, or Lisa Appignanesi, Rachel Castell Farhi, Jenny Diski and Tamar Yellin, many of them of a younger generation, explore critically the creative tension which is offered by different forms of identification in twenty-first-century Britain.

In 1967 Toynbee conceded that it was 'an odd thought' that 'our most distinguished Jewish writer is probably Leonard Woolf, a man so utterly assimilated into a particular section of the upper English middle class that he seems to have shed every trace of exoticism which may have encompassed him' ${ }^{17}$ Odd indeed, but so too are, to our more recent sensibilities, the assumptions underlying this remark.

For one, Toynbee appears to suggest assimilation and exoticism as the characteristic parameters between which Jewish literary production in Britain is contained. The distinctive feature of truly authentic Jewish writing would then be its exoticism which manifests itself to varying degrees in reverse correlation with the writer's powers of assimilation. The very notion of the exotic is of course problematic; not least, because it favours not only a Eurocentric but, even more specifically, an Anglocentric perspective which is taken to be the standard against which deviations are measured. Toynbee's suggestion that Woolf was 'our most distinguished Jewish writer' ${ }^{18}$ is an illustration of the fixity of English patterns of identification observed by Bryan Cheyette. ${ }^{19}$ Moreover, the exotic at least implicitly seems to be devalued in contrast to assimilation which, in turn, and probably unintentionally in Toynbee's case, suggests a clear hierarchy in British literary production.

No less significant is Toynbee's assertion that Leonard Woolf was Britain's 'most distinguished' Jewish writer. Given Woolf's absolute 'un-Jewishness' this appears paradoxical in itself. Indeed, Leonard Woolf is hardly ever thought of as a British Jewish writer and much less a Jewish writer, even though, as Toynbee hastens to add, he 'has never tried to be un-Jewish'. ${ }^{20}$ Nevertheless, as the reviewer explains, 'his background - public school and Cambridge; the British Colonial Service and the high artistic atmosphere of Bloomsbury - have left far more obvious marks on him than his Jewish origins have been able to leave'. ${ }^{21}$ The underlying assumption in this case seems to be that Woolf is the best known of 'biologically' Jewish writers in Britain. This 
suggestion is problematic in itself, for obvious reasons, but it also furnishes Toynbee with the confirmation of his claim that there is no British Jewish literature. It reveals, moreover, that Toynbee's perception of Jewishness is determined by his own Britishness to which the former appears to be alien and exotic. And it is perhaps characteristic of this outside perception that it seems to be blithely unaware of differences within the Jewish context and completely ignores writers such as Brian Glanville, Bernard Kops and Gerda Charles. These were well known, not as pinnacles of English literature, but as exponents of British Jewish literature, though they were not, perhaps, the most 'distinguished' - the latter being a category applied from the perspective not only of English literature but tinged, or even tainted, by social arrogance. Even though this kind of Britishness may have sat uneasily on Toynbee himself, whose background was not so much different from Woolf's but who then became a Marxist, it is indicative of the deeply pervasive power of notions of Britishness.

Almost none of these earlier British Jewish writers have made it into the mainstream and they are, at least in public discourse, all but forgotten. The cosmopolitanism of Jewish writing in Britain in the period prior to the SixDay War also seems to be a thing of the past. Yet, if we look at contemporary Jewish writing in Britain, as the eight contributions to this special issue do, we may wonder if there is not, in some more or less subtle ways, a new exoticism adhering to it which, affirmative as it may be, is the product of debates on multiculturalism and the concomitant focus on religious and ethnic identities that has shaped much of British literature in general. We may then also wonder how far contemporary British Jewish writing is a response to more recent policies of 'community cohesion' that nevertheless reaffirm notions of integration and, as some fear, of assimilation, monoculturalism and nativism.

\section{Notes}

1. Bryan Cheyette (ed.), Contemporary Jewish Writing in Britain and Ireland: An Anthology, Halban, London 1998, pp. xiii-lxxi, p. lxiv.

2. Donald Weber, 'Anglo-Jewish Literature Raises Its Voice', 2007, JBooks, available at http://www.jbooks. com/interviews/index/IP_Weber_English.htm (accessed 24 February 2014).

3. For a report on the symposium, see Axel Stähler and Sue Vice, 'Writing Jews in Contemporary Britain', Jewish Quarterly 60, nos 3-4, 2013, 117-18.

4. Dannie Abse et al., 'Israel - A Right to Live', The Sunday Times, 4 June 1967.

5. Philip Toynbee, 'Fathers and Sons', The New Republic 156, 17 June 1967, 21-22, 21.

6. Ibid.

7. Ibid. 
8. Brian Glanville, 'The Anglo-Jewish Writer', Encounter 24, no. 2, 1960, 62-64, 62.

9. Cheyette (ed.), Contemporary Jewish Writing in Britain and Ireland, p. xxvii.

10. Brian Glanville, 'The Man behind the Pen: (1) - Wolf Mankowitz', The Jewish Chronicle, no. 4678, 19 December 1958, p. 19; 'The Man Behind the Pen: (2) - Peter Shaffer', no. 4679, 26 December 1958, p. 13; 'The Man Behind the Pen: (3)-Alexander Baron', no. 4680, 2 January 1959, p. 17; 'The Man Behind the Pen: (4) - Bernard Kops / (5) - Arnold Wesker', no. 4681, 9 January 1959, p. 17; 'The Man Behind the Pen: (6) - Dannie Abse', no. 4682, 16 January 1959, p. 19. See further Chaim Bermant, Troubled Eden: An Anatomy of British Jewry, Vallentine, Mitchell, London 1969, pp. 162-64; Efraim Sicher, Beyond Marginality: Anglo-Jewish Literature after the Holocaust, State University of New York Press, Albany 1985, pp. 21-22; David Cesarani, The Jewish Chronicle and Anglo-Jewry, 1841-1991, Cambridge University Press, Cambridge 1994, pp. 213-14; and Cheyette (ed.), Contemporary Jewish Writing in Britain and Ireland, pp. xxvi-xxvii. The interview series itself was advertised as 'Important New Series Next Week: "The Man Behind the Pen"' in The Jewish Chronicle, no. 4677, 12 December 1958, p. 1 by situating these writers in the larger context of English literature and its recent trends: 'Their writing and the literary reviews show that Anglo-Jewry contributes its quota to the angry young men of this generation.' The interviews, though expected to be shocking, were justified by pointing out that 'they are bound to stimulate fresh thinking. If we are to deal constructively with the problems of today the views of men like these should be known.' In response to the interview series, see also Israel Finestein et al., 'Young Jewish Writers and the Community: What Is the Answer?', The Jewish Chronicle, no. 4683, 23 January 1959, p. 17.

11. Brian Glanville, 'The Man Behind the Pen: (2) - Peter Shaffer', The Jewish Chronicle, no. 4679, 26 December 1958, p. 13.

12. The exceptions were Peter Shaffer and Arnold Wesker.

13. Asked in an interview in 1963 'What is the impact of Israel on your work?', Alexander Baron obviously spoke not only for himself when he answered: 'None. I am myself deeply interested in Israel. I have painful hopes for it and, I may add, no small fears. But I've tried to show that a writer lives in a world, a vision, that is not of his conscious creating, and so far - I can't say what will happen in the future - the fact of Israel hasn't entered into my writer's imaginative world.' Alexander Baron, 'On Being English and Jewish', Jewish Quarterly 10, no. 1, 1963, 6-10, 10. Brian Glanville and Frederic Raphael responded similarly in the following year. The former asserted: 'I regard the foundation of Israel as the most moving and deeply significant event in my life, but I don't think it has a direct effect on my work. Nor have I yet been there; I am content to know that it exists.' Brian Glanville, 'On Being English and Jewish: An Enquiry', Jewish Quarterly 11, no. 3 1963, 3-5, 5. The latter put it even more concisely, and perhaps a little ambivalently, when he claimed: 'Nil. I want to go there of course, but my work ... No. How inadequate it is!' Frederic Raphael, 'On Being English and Jewish', Jewish Quarterly 11, no. 3, 1963, 6-8, 8 .

14. The complete list of signatories includes: Dannie Abse, Al Alvarez, Alexander Baron, Chaim Bermant, Myrna Blumberg, Caryl Brahms (born Doris Caroline Abrahams), Ronald Cass, Gerda Charles (born Edna Lipson), Sid Collin, David Daiches, Lionel Davidson, Marty Feldman, Tosco R. Fyvel, Larry Gelbart, Diana and Meir Gillon, Martyn Goff, Lewis Greifer, John Cross, Ronald Harwood (born Horwitz), Dan Jacobson, Bernard Kops, Philip Levene, Emmanuel Litvinoff, Wolf Mankowitz, 
Stanley Mann, Louis Marks, Robert Muller, Denis Norden, Harold Pinter, Frederic Raphael, Mordecai Richler, Jeremy Robson, Reuben Ship, Jacob Sonntag and George Steiner.

15. For a discussion of the problems of definition in this context, see Mark Stein, Black British Literature: Novels of Transformation, Ohio State University Press, Columbus 2004, pp. 8-9.

16. Bryan Cheyette, 'Englishness and Extraterritoriality: British-Jewish Writing and Diaspora Culture', Literary Strategies: Studies in Contemporary Jewry 12, 1996, 21-39.

17. Toynbee, 'Fathers and Sons', 21 (emphasis added).

18. Ibid. (emphasis added).

19. See Cheyette (ed.), Contemporary Jewish Writing in Britain and Ireland, p. xliii.

20. Toynbee, 'Fathers and Sons', 21 (emphasis in the original).

21. Ibid. 